\title{
NATURALNESS EXPRESSED IN SEM-VALUES
}

In Slovenia, natural syntax of the Klagenfurt brand has been extended to "the Slovenian Theory", which studies the behaviour of (near)synonymous syntactic expressions, here called syntactic variants. The essential apparatus consists of combinations of high and low sym-and sem-values culled from naturalness scales.

The present paper adduces examples of a high sem-value combined with another high sem-value, and of a low sem-value combined with another low sem-value. Such combinations have so far not received any attention in Naturalness Theory.

The illustrations utilize language material divided into 14 "deductions." For the list of languages, see Keywords.

Keywords: naturalness, syntax, morphosyntax; Albanian, Estonian, French, old Germanic languages, Gothic, Hungarian, Italian, Lakhota, Lappish, Paiute, old and modern Russian, Slovenian.

The subject-matter of my paper is a (language-universal) theory developed in Slovenia by a small group of linguists (under my guidance), who mainly use English, German, and Slovenian language material as the base of verification. Our work owes much to, and exploits, the (linguistic) Naturalness Theory as elaborated especially at some Austrian and German universities; cf. Mayerthaler 1981, Wurzel 1984, Dressler et al. 1987, Stolz 1992, Dressler 2000. Naturalness Theory has also been applied to syntax, notably at the University of Klagenfurt; the basic references are Dotter 1990, Mayerthaler \& Fliedl 1993, Mayerthaler et al. 1993, 1995, 1998. Within the natural syntax of the Klagenfurt brand, the Slovenian work group has built an extension, which will henceforth be referred to as "the Slovenian Theory."

The Slovenian Theory studies the behaviour of (near-)synonymous syntactic expressions, here called syntactic variants. Whenever two syntactic variants are included in the same naturalness scale, and consequently one variant can be asserted to be more natural than the other, the Slovenian Theory has something to say about some grammatical properties of the two variants.

Naturalness Theory operates with two basic predicates, "marked" and "natural." I cannot see any reason to distinguish the two predicates within the Slovenian Theory, therefore I use throughout one predicate only, namely "natural." (This standpoint was implied as early as Mayerthaler 1987, 50.)

Beside the technical terms "natural(ness)" and "naturalness scale," which have already been alluded to, the terms "sym-value" and "sem-value" (adopted from Mayerthaler 1981, 10 et passim) must be mentioned. The sym-value refers to the naturalness of an expression in terms of its encoding properties. The sem-value refers to the naturalness of an expression in terms of its semantic complexity. 
The following auxiliary symbols will be employed:

">sym" (= more natural with respect to encoding),

"<sym" (= less natural with respect to encoding),

">sem" (= more natural with respect to semantic complexity), and

"<sem" (= less natural with respect to semantic complexity).

The assumptions of the Slovenian Theory (in my recently revised version) can be briefly stated as follows.

In a pair of syntactic variants, within each variant, one of the following alternatives obtains:

(1) at least one >sym-value tends to associate with at least one additional >sym-value and/or with at least one <sem-value;

(2) at least one $<$ sym-value tends to associate with at least one additional $<$ sym-value and/or with at least one >sem-value;

(3) at least one $>$ sem-value tends to associate with at least one additional $>$ sem-value and/or with at least one <sym-value;

(4) at least one <sem-value tends to associate with at least one additional $<$ sem-value and/or with at least one $>$ sym-value.

In the above items (1-4) the object of the meta-verb "associate" refers to the interior of the unit under observation, OR to a part of the immediate environment of the unit under observation. The Slovenian Theory covers both cases.

Forschungsgeschichtlich, the predecessor of the above assumptions (1-4) is the familiar principle of constructional iconicity as formulated in Natural Morphology. The principle runs as follows. Iff a semantically more marked category $C_{j}$ is encoded as 'more' featured than a less marked category $C_{i}$, the encoding of $C_{j}$ is said to be iconic (Mayerthaler 1987, 48-9). Using the predicate "natural," the principle can be briefly stated as follows: <sem in combination with >sym is iconic. In the Slovenian Theory, the principle has been extended to syntax and expanded. Five published papers utilizing this framework: Orešnik 1999, 2000a,b, 2001a,b.

Each case considered is presented in the format of a deduction. A straightforward example:

1. Slovenian. The masculine singular nominative of the cardinal numeral 'one' is en when accompanied by a mention of the unit counted, and eden when not accompanied by a mention of the unit counted, e.g. samo en clovek je prišel 'only one man came,' samo eden je prišel 'only one came.' (Cf. Toporišič 2000, 330.)

The two syntactic variants: eden, en the masculine singular nominative of 'one.'

1. The assumptions of Naturalness Theory:

1.1. >sym (more transparent, less transparent) / morphological unit

I.e. with respect to encoding, a morphological unit of greater transparency is more natural than a corresponding morphological unit of lesser transparency. (Mayerthaler 1981, 35; Mayerthaler et al. 1998, 186. On the notion of transparency see Mayerthaler 1987, 49.) 
A special case of 1.1:

1.1.1. >sym (eden, en) / masculine nominative singular of 'one' in Slovenian

I.e. with respect to encoding, the masculine nominative singular eden is more natural than the masculine nominative singular en, in Slovenian.-Eden is more transparent than en, because eden has more sound body and internal structure.

1.2. >sem (+mention, -mention) / of the unit counted with the cardinal numeral

I.e. with respect to semantic complexity, a cardinal numeral + the unit counted is more natural than a cardinal numeral not accompanied by the unit counted.-The prevalent typological situation is that the cardinal numeral is accompanied by a mention of the unit counted.

2. The assumptions of the Slovenian Theory, concerning any two syntactic variants:

2.1. > sym tends to associate with $<$ sem

2.2. <sym tends to associate with $>$ sem

3. The consequences:

From 1.1.1, 1.2 and 2.1 it can be deduced:

3.1. If there is any difference between the forms of masculine singular eden and en, such that one form is accompanied by a mention of the unit counted, and the other form is not accompanied by a mention of the unit counted, it is the form eden that tends not to be accompanied by a mention of the unit counted. Q.E.D.

From 1.1.1, 1.2 and 2.2 it can be deduced:

3.2. If there is any difference between the forms of masculine singular eden and en, such that one form is accompanied by a mention of the unit counted, and the other form is not accompanied by a mention of the unit counted, it is the form en that tends to be accompanied by a mention of the unit counted. Q.E.D.

In the remainder of the present paper cases are adduced in which a high sem-value associates with another high sem-value, and a low sem-value associates with another low sem-value. Such combinations have so far not received any systematic attention in the Naturalness Theory. Consider the following deductions (2-14):

2. Albanian. Pronominal possessor, third person, alienable and inalienable possession. In inalienable possession, the same form is used for the singular and for the plural, e.g. e ëm- $a$ 'his/her/their mother;' the possessor is not expressed. In alienable possession, a separate form is used for the masculine and feminine singular, and a separate for the plural, thus shoq-ja e tij 'his female colleague,' shoq-ja e saj 'her female colleague,' shoq-ja e tyre 'their female colleague;' the possessor is expressed. (Lyons 1999, 129; supplemented with Snoj 1991, 53 ff.)

The two syntactic variants: the type $e$ ëm- $a$, and the type shoq-ja e tij.

1. The assumptions of Naturalness Theory:

1.1. >sem ('his/her/their;' 'his,' 'her,' 'their') / pronominal possessor in Albanian 
I.e. with respect to semantic complexity, the expression of 'his,' 'her' and 'their' with one form is more natural than the expression of these three separately, in Albanian. $-\mathrm{A}$ form with several meanings has a higher sem-value than a corresponding form with fewer meanings. Recall that dictionary entries of the most frequent lexical items tend to be much longer (enumerate more meanings) than dictionary entries of infrequent lexical items. Lexical items of high frequency have a high sem-value.

1.2. >sem (-alienable, +alienable) / possession

I.e. with respect to semantic complexity, inalienable possession is more natural than alienable possession. (Mayerthaler 1981, 152; Mayerthaler et al. 1998, 275.)

2. The assumptions of the Slovenian Theory, concerning any two syntactic variants:

2.1. $>$ sem tends to associate with another $>$ sem

2.2. $<$ sem tends to associate with another $<$ sem

3. The consequences:

From $1.1-2$ and 2.1 it can be deduced:

3.1. If there is any difference between the type $e \ddot{e m}-a$ and the type shoq-ja e tij, such that one expresses three meanings of the possessor, and the other expresses just one meaning of the possessor, and such that one expresses alienable possession, and the other expresses inalienable possession, it is the type $e$ ëm- $a$ that tends to express inalienable possession and several meanings of the possessor. Q.E.D.

From $1.1-2$ and 2.2 it can be deduced:

3.2. If there is any difference between the type $e \ddot{e} m-a$ and the type shoq-ja e tij, such that one expresses three meanings of the possessor, and the other expresses just one meaning of the possessor, and such that one expresses alienable possession, and the other expresses inalienable possession, it is the type shoq-ja e tij that tends to express alienable possession and just one meaning of the possessor. Q.E.D.

3. Estonian. A predicative noun can be expressed with the nominative or with the essive. (After change-of-state verbs with the translative; this case is not treated here.) If the nominative is used, it implies permanency (even inalienable capacities), e.g. mees on meie saadik Londonis 'he is our [permanent] ambassador in London.' If the essive is employed, it implies contingency, e.g. mees on meie saadikuna Londonis 'he is our [not necessarily permanent] ambassador in London.' Similarly in predicative nouns and adjectives of Finnish. (Anderson 1999, 63.)

The two syntactic variants: the predicative noun in the nominative, and the predicative noun in the essive.

1. The assumptions of Naturalness Theory:

1.1. >sem (nominative, other cases) / in nom.-acc. languages

I.e. with respect to semantic complexity, the nominative is more natural than other cases, in nominative-accusative languages.-This follows from the basic properties of nominative-accusative languages. (Mayerthaler et al. 1998, 241.)

1.2. >sem (-alienable, +alienable) / property 
I.e. with respect to semantic complexity, an inalienable property is more natural than an alienable property. (Mayerthaler 1981, 152; Mayerthaler et al. 1998, 275.)

A special case of 1.2:

1.2.1. >sem (+permanent, -permanent) / property

I.e. with respect to semantic complexity, a permanent property is more natural than a non-permanent property.

2. The assumptions of the Slovenian Theory, concerning any two syntactic variants:

2.1. $>$ sem tends to associate with another $>$ sem

2.2. $<$ sem tends to associate with another $<$ sem

3. The consequences:

From 1.1, 1.2.1 and 2.1 it can be deduced:

3.1. If there is any difference between the predicative noun in the nominative and in the essive, such that one case expresses permanent property, and the other case expresses non-permanent property, it is the nominative that tends to express the permanent property. Q.E.D.

From 1.1, 1.2.1 and 2.2 it can be deduced:

3.2. If there is any difference between the predicative noun in the nominative and in the essive, such that one case expresses permanent property, and the other case expresses non-permanent property, it is the essive that tends to express the non-permanent property. Q.E.D.

4. French. If the possessum is definite and the possessor pronominal, the latter is expressed with a possessive adjective, e.g. ma bicyclette 'my bicycle.' In other cases of possession, a prepositional phrase is used after the possessum, e.g. la bicyclette de Jeanne 'Jeanne's bicycle,' une bicyclette à Jeanne, à moi 'a bicycle of Jeanne's, of mine.' (Lyons 1999, 130.)

The two syntactic variants: the type la bicyclette de Jeanne, and the type une bicyclette à Jeanne.

1. The assumptions of Naturalness Theory:

1.1. >sem (genitive, other cases) / case dependent on a head noun, in nom.-acc. languages

I.e. with respect to semantic complexity, the genitive is more natural than other cases dependent on a head noun, in nominative-accusative languages.-The genitive is the adnominal case par excellence.

1.2. >sem (+presupposed, -presupposed)

I.e. with respect to semantic complexity, +presupposed is more natural than -presupposed. (Mayerthaler 1981, 14.)

A special case of 1.2:

1.2.1. >sem (+definite, -definite)

I.e. with respect to semantic complexity, +definite is more natural than -definite.-Everything definite is presupposed. 
2. The assumptions of the Slovenian Theory, concerning any two syntactic variants:

2.1. $>$ sem tends to associate with another $>$ sem

2.2. $<$ sem tends to associate with another $<$ sem

3. The consequences:

From 1.1, 1.2.1 and 2.1 it can be deduced:

3.1. If there is any difference between the type la bicyclette de Jeanne and the type une bicyclette a Jeanne, such that one type is definite, and the other indefinite, and such that the possessor is in the genitive or in the dative case, it is the definite type that tends to contain a genitive. Q.E.D.

From 1.1, 1.2.1 and 2.2 it can be deduced:

3.2. If there is any difference between the type la bicyclette de Jeanne and the type une bicyclette à Jeanne, such that one type is definite, and the other indefinite, and such that the possessor is in the genitive or in the dative case, it is the indefinite type that tends to contain a dative. Q.E.D.

5. French. While French has distinct reflexive and non-reflexive third person pronouns, it does not make such a distinction for the other persons, but instead uses the same first and second person pronouns both reflexively and non-reflexively, e.g. je me vois 'I see me = myself,' as opposed to ils les/se voient 'they see them/themselves.' (Schachter 1985, 27-8.) Similarly in some other languages (Lichtenberk 1999, 314).

The two syntactic variants: the reflexive pronoun, and the personal pronoun, both expressing reflexivity.

1. The assumptions of Naturalness Theory:

1.1. >sem (reflexive, personal) / pronoun expressing reflexivity

I.e. with respect to semantic complexity, a reflexive pronoun is more natural than a personal pronoun, as an expression of reflexivity.-If a language has a specialized means of expressing a category, that specialized means is more sem-natural than other means of expressing the same category. (My guess.)

1.2. >sem (+third, -third) / grammatical person

I.e. with respect to semantic complexity, the third grammatical person is more natural than the non-third grammatical person. (According to the linguistic tradition beginning with Jakobson 1932.)

2. The assumptions of the Slovenian Theory, concerning any two syntactic variants:

2.1. > sem tends to associate with another $>$ sem

2.2. $<$ sem tends to associate with another $<$ sem

3. The consequences:

From 1.1, 1.2 and 2.1 it can be deduced:

3.1. If there is any difference between personal and reflexive pronouns as an expression of reflexivity, such that one kind of pronouns is used in the third person, and the other kind of pronouns in the non-third person, it is the reflexive pronouns that tend to be used in the third person. Q.E.D. 
From 1.1, 1.2 and 2.2 it can be deduced:

3.2. If there is any difference between personal and reflexive pronouns as an expression of reflexivity, such that one kind of pronouns is used in the third person, and the other kind of pronouns in the non-third person, it is the personal pronouns that tend to be used in the non-third person. Q.E.D.

6. Germanic languages, old. The verb of the relative clause is in the indicative mood if the superordinate clause is affirmative. The verb of the relative clause is in the subjunctive mood if the superordinate clause is negative. (M. Kozianka 1999.)

The two syntactic variants: the relative clause containing the finite verb in the indicative mood, and the relative clause containing the finite verb in the subjunctive mood.

1. The assumptions of Naturalness Theory:

1.1. >sem (affirmation, negation)

I.e. with respect to semantic complexity, affirmation is more natural than negation. (Mayerthaler 1981, 15, 159.)

1.2. $>$ sem (+indicative, -indicative)

I.e. with respect to semantic complexity, the indicative is more natural than nonindicative. (Mayerthaler 1981, 14.)

A special case of 1.2:

1.2.1. >sem (indicative, subjunctive) / in old Germanic languages

I.e. with respect to semantic complexity, the indicative is more natural than the subjunctive, in the old Germanic languages.

2. The assumptions of the Slovenian Theory, concerning any two syntactic variants:

2.1. $>$ sem tends to associate with another $>$ sem

2.2. $<$ sem tends to associate with another $<$ sem

3. The consequences:

From 1.1, 1.2.1 and 2.1 it can be deduced:

3.1. If there is any difference between affirmative superordinate clause + relative clause and negative superordinate clause + relative clause, such that the mood of the relative clause is indicative or subjunctive, the relative clause's verb tends to be in the indicative mood if the superordinate clause is affirmative. Q.E.D.

From 1.1, 1.2.1 and 2.2 it can be deduced:

3.2. If there is any difference between affirmative superordinate clause + relative clause and negative superordinate clause + relative clause, such that the mood of the relative clause is indicative or subjunctive, the relative clause's verb tends to be in the subjunctive mood if the superordinate clause is negated. Q.E.D.

7. Gothic. The dual lacks the third verbal person (in the verb and in the personal pronoun). (Braune \& Ebbinghaus 1966, 98.) The third verbal person of the dual is replaced by the third verbal person of the plural. (Hirt 1932, 139; 1934, 10, with references.) 
The two morphological variants: the third person dual, and the non-third person dual.

1. The assumptions of Naturalness Theory:

1.1. >sem (plural, dual)

I.e. with respect to semantic complexity, the plural is more natural than the dual. (Greenberg 1966, 31-7.)

1.2. >sem (+third, -third) / grammatical person

I.e. with respect to semantic complexity, the third person is more natural than the non-third person. (According to the linguistic tradition beginning with Jakobson 1932.)

A special case of 1.2:

1.2.1. >sem (+third, -third) / grammatical person of the dual

I.e. with respect to semantic complexity, the third person is more natural than the non-third person, in the dual.

2. The assumptions of the Slovenian Theory, concerning any two morphological variants:

2.1. $>$ sem tends to associate with another $>$ sem

2.2. $<$ sem tends to associate with another $<$ sem

3. The consequences:

From 1.1, 1.2.1 and 2.1 it can be deduced:

3.1. If there is any difference between the third person dual and the non-third person dual, such that one set of persons uses special dual forms, and the other set of persons uses plural forms, it is the third person dual that tends to use plural forms. Q.E.D.

From 1.1, 1.2.1 and 2.2 it can be deduced:

3.2. If there is any difference between the third person dual and the non-third person dual, such that one set of persons uses special dual forms, and the other set of persons uses plural forms, it is the non-third person dual that tends to use special dual forms. Q.E.D.

8. Hungarian. The basic element order is SVO. However, objects and other arguments with no article are placed in front of the (nonprefixed) verb; they are nonspecific and often form a semantic unit with the verb up to idiomaticity, e.g. Péter könyvet olvas Peter book read 'Peter is reading books / a book.' Thus the element order is SOV. (Kenesei et al. 1998, 73-4.)

The two syntactic variants: the basic element order SVO, and the basic element order SOV.

1. The assumptions of Naturalness Theory:

1.1. >sem (SOV, SVO) / basic element order

I.e. with respect to semantic complexity, the basic element order SOV is more natural than the basic element order SVO. (Mayerthaler et al. 1998, 309. Cf. the discussion in A. Siewierska 1999, 412-3.)

1.2. >sem (-definite, + definite) / direct object 
I.e. with respect to semantic complexity, the indefinite direct object is more natural than the definite direct object.-In the spirit of Mayerthaler 1981, 14 and 1987, 42, concerning the markedness relations of the object as being the opposite of those typical of the subject.

2. The assumptions of the Slovenian Theory, concerning any two syntactic variants:

2.1. $>$ sem tends to associate with another $>$ sem

2.2. $<$ sem tends to associate with another $<$ sem

3. The consequences:

From $1.1,1.2$ and 2.1 it can be deduced:

3.1. If there is any difference between the basic element orders SVO and SOV, such that one is used with +definite objects, and the other is used with -definite objects, it is SOV that tends to be used with -definite objects. Q.E.D.

From 1.1, 1.2 and 2.2 it can be deduced:

3.2. If there is any difference between the basic element orders SVO and SOV, such that one is used with +definite objects, and the other is used with -definite objects, it is SVO that tends to be used with +definite objects. Q.E.D.

9. Italian. The affirmative imperative of the second person singular is a finite form, e.g. ridi 'laugh.' The corresponding negative imperative consists of the negative word non + infinitive, e.g. non ridere 'do not laugh.'

The two syntactic variants: the affirmative imperative of the second person singular, and the corresponding negative imperative.

1. The assumptions of Naturalness Theory:

1.1. >sem (affirmation, negation)

I.e. with respect to semantic complexity, affirmation is more natural than negation. (Mayerthaler 1981, 15, 159.)

1.2. $>$ sem (+finite, - finite) / verbal form

I.e. with respect to semantic complexity, a finite form of the verb is more natural than an infinite form of the verb. (Mayerthaler et al. 1993, 145.)

A special case of 1.2:

1.2.1. >sem (finite form, infinitive) / in Italian

I.e. with respect to semantic complexity, a finite form is more natural than the infinitive, in Italian.

2. The assumptions of the Slovenian Theory, concerning any two syntactic variants:

2.1. $>$ sem tends to associate with another $>$ sem

2.2. $<$ sem tends to associate with another $<$ sem

3. The consequences:

From 1.1, 1.2.1 and 2.1 it can be deduced:

3.1. If there is any difference between the affirmative and negative imperatives concerning their formal structure, such that one is a finite verb, and the other an infinitive, it is the affirmative imperative that tends to assume the form of a finite verb. Q.E.D. 
From 1.1, 1.2.1 and 2.2 it can be deduced:

3.2. If there is any difference between the affirmative and negative imperatives concerning their formal structure, such that one is a finite verb, and the other an infinitive, it is the negative imperative that tends to be expressed with the infinitive. Q.E.D.

10. Lakhota (a dialect of Dakota, one of the Siouan languages). Within the first person singular, the prefix for kinship terms is $m i-$; the prefix for body parts is $m a-$. (Lyons 1999, 129.)

The two syntactic variants: the prefix $m i-$, and the prefix $m a-$, both for inalienable possession in the first person singular.

1. The assumptions of Naturalness Theory:

1.1. >sem (body part, kinship relation) / inalienable possession

I.e. with respect to semantic complexity, body parts are more natural than kinship relations, as instances of inalienable possession.-This is based on the circumstance that some languages, e.g. Dyirbal (Lyons 1999, 129), treat kinship relations as alienable.

1.2. >sem ( $m a-, m i-) /$ inalienable possession in the first person singular, in Lakhota

I.e. with respect to semantic complexity, $m a$ - is more natural than $m i$ - as an expression of inalienable possession in the first person singular, in Lakhota.-This is based on the circumstance that $m a$ - is specialized for inalienable possession. The prefix $m i$ - is used for alienable possession as well, e.g. in 'my dog' (Lyons 1999, 127).

2. The assumptions of the Slovenian Theory, concerning any two syntactic variants:

2.1. $>$ sem tends to associate with another $>$ sem

2.2. $<$ sem tends to associate with another $<$ sem

3. The consequences:

From $1.1,1.2$ and 2.1 it can be deduced:

3.1. If there is any difference between the prefixes $m a$ - and $m i$ - for inalienable possession in the first person singular, such that one prefix is used for body parts, and the other for kinship terms, it is the prefix ma- that tends to be used for body parts. Q.E.D.

From 1.1, 1.2 and 2.2 it can be deduced:

3.2. If there is any difference between the prefixes $m a$ - and $m i$ - for inalienable possession in the first person singular, such that one prefix is used for body parts, and the other for kinship terms, it is the prefix $m i$ - that tends to be used for kinship terms. Q.E.D.

11. Lappish, Southern. A definite direct object is in the accusative case, while an indefinite direct object is in the nominative case. (Schachter 1985, 41, referring to Wickman.) My interpretation: A definite direct object is in the accusative which formally does not equal the nominative, while an indefinite direct object is in the accusative case which formally equals the nominative.

The two syntactic variants: definite direct object, and indefinite direct object.

1. The assumptions of Naturalness Theory: 


\section{1. >sem (-definite, +definite) / direct object}

I.e. with respect to semantic complexity, the indefinite direct object is more natural than the definite direct object.-In the spirit of Mayerthaler 1981, 14 and 1987, 42, concerning the markedness relations of the object as being the opposite of those typical of the subject.

1.2. >sem (conflated, separated) / accusative and nominative

I.e. with respect to semantic complexity, accusative and nominative conflated is more natural than accusative and nominative separated.-A form with several meanings has a higher sem-value than a corresponding form with fewer meanings. Cf. item 1.1 of deduction 2 .

2. The assumptions of the Slovenian Theory, concerning any two syntactic variants:

2.1. >sem tends to associate with another $>$ sem

2.2. $<$ sem tends to associate with another $<$ sem

3. The consequences:

From $1.1-2$ and 2.1 it can be deduced:

3.1. If there is any difference between the definite and indefinite direct objects, such that one takes the accusative case which equals the nominative case, and the other takes the accusative case which does not equal the nominative case, it is the indefinite direct object that takes the accusative case which equals the nominative case in form. Q.E.D.

From $1.1-2$ and 2.2 it can be deduced:

3.2. If there is any difference between the definite and indefinite direct objects, such that one takes the accusative case which equals the nominative case, and the other takes the accusative case which does not equal the nominative case, it is the definite direct object that takes the accusative case which does not equal the nominative case in form. Q.E.D.

12. Paiute, Southern (Paiute is a Uto-Aztecan language spoken in small areas of the USA). Demonstrative and third-person personal pronouns are not distinguished, e.g. aya 'that one' and 'he;' ina 'this one' and 'he;' ari 'that one' and 'it.' (Schachter 1985, 30, referring to Sapir.) Since the forms enumerated indicate distant vs. near reference, they are primarily demonstrative pronouns, in addition serving as personal pronouns.-Similarly in Latin.

The two syntactic variants: third-person personal and demonstrative pronoun, and non-third-person personal pronoun.

1. The assumptions of Naturalness Theory:

1.1. >sem (conflated, separated) / personal and demonstrative pronoun

I.e. with respect to semantic complexity, a personal and a demonstrative pronoun conflated is more natural than a personal and a demonstrative pronoun separated. $\mathrm{A}$ form with several meanings has a higher sem-value than a corresponding form with fewer meanings. Cf. item 1.1 of deduction 2 . 


\section{2. >sem (+third, -third) / grammatical person}

I.e. with respect to semantic complexity, the third grammatical person is more natural than the non-third grammatical person. (According to the linguistic tradition beginning with Jakobson 1932.)

2. The assumptions of the Slovenian Theory, concerning any two syntactic variants:

2.1. > sem tends to associate with another $>$ sem

2.2. <sem tends to associate with another $<$ sem

3. The consequences:

From $1.1-2$ and 2.1 it can be deduced:

3.1. If there is any difference between being a personal OR a demonstrative pronoun and being a personal AS WELL AS demonstrative pronoun, such that one option is used in the third person, and the other option is used in the non-third person, the option of being a personal AND a demonstrative pronoun tends to be used in the third person. Q.E.D.

From $1.1-2$ and 2.2 it can be deduced:

3.2. If there is any difference between being a personal OR a demonstrative pronoun and being a personal AS WELL AS demonstrative pronoun, such that one option is used in the third person, and the other option is used in the non-third person, the option of being a personal $\mathrm{OR}$ a demonstrative pronoun tends to be used in the nonthird person. Q.E.D.

13. Russian, Old, Northern. Non-animate direct objects of the infinitive stand in the nominative case, e.g. zeml'a paxati land (nom. sg.) plough (inf.) 'to plough the land.' The construction can only be observed in the feminine singular, for morphological reasons. (Tschernych 1957, 265-7.)

The two syntactic variants: zeml 'u paxaju 'I plough the land,' and zeml'a paxat' 'to plough the land.'

1. The assumptions of Naturalness Theory:

1.1. >sem ( + finite, - finite) / verbal form

I.e. with respect to semantic complexity, a finite verbal form is more natural than a non-finite verbal form. (Mayerthaler et al. 1993, 145.)

A special case of 1.1 :

1.1.1. >sem (finite verbal form, infinitive) / in Old Northern Russian

I.e. with respect to semantic complexity, a finite verbal form is more natural than an infinitive, in Old Northern Russian.

1.2. >sem (accusative, nominative) / as the case of the direct object

I.e. with respect to semantic complexity, the accusative is more natural than the nominative, as the case of the direct object. (In the spirit of Mayerthaler 1981, 14.)

A special case of 1.2:

1.2.1. >sem (accusative, nominative) / as the case of the inanimate direct object in Old Northern Russian 
I.e. with respect to semantic complexity, the accusative is more natural than the nominative, as the case of the inanimate direct object in Old Northern Russian.

2. The assumptions of the Slovenian Theory, concerning any two syntactic variants:

2.1. > sem tends to associate with another $>$ sem

2.2. $<$ sem tends to associate with another $<$ sem

3. The consequences:

From 1.1.1, 1.2.1 and 2.1 it can be deduced:

3.1. If there is any difference between the inanimate direct object of a finite verb, and the inanimate direct object of an infinitive (such that the choice is between the direct object in the accusative and in the nominative), it is the inanimate direct object of the finite verb that tends to be in the accusative case. Q.E.D.

From 1.1.1, 1.2.1 and 2.2 it can be deduced:

3.2. If there is any difference between the inanimate direct object of a finite verb, and the inanimate direct object of an infinitive (such that the choice is between the direct object in the accusative and in the nominative), it is the inanimate direct object of the infinitive that tends to be in the nominative case. Q.E.D.

14. Russian. Russian favors SVO in the formal written language but SOV in the colloquial language. (A. Siewierska 1999 , 413.) This is only partly confirmed in E. Zemskaja 1979, 149-50, where examples of both SVO and SOV are adduced from colloquial language.

The two syntactic variants: conversation, and the other registers.

1. The assumptions of Naturalness Theory:

1.1. >sem (conversation, other registers)

I.e. with respect to semantic complexity, conversation is more natural than other registers. (Dotter 1990, 228.)

1.2. >sem (SOV \& SVO, only SVO) / basic element order of declarative clauses

I.e. with respect to semantic complexity, a declarative clause which admits SOV and SVO is more natural than a declarative clause which admits only SVO.-The scale has the format $>\operatorname{sem}(A+B, A)$. See Note 4 .

2. The assumptions of the Slovenian Theory, concerning any two syntactic variants:

2.1. > sem tends to associate with another $>$ sem

2.2. $<$ sem tends to associate with another $<$ sem

3. The consequences:

From 1.1, 1.2 and 2.1 it can be deduced:

3.1. If there is any difference between conversation and the other registers concerning their basic element order, such that one kind of register admits SVO and SOV, and the other kind of register admits only SVO, it is conversation that tends to admit SVO and SOV. Q.E.D.

From 1.1, 1.2 and 2.2 it can be deduced: 
3.2. If there is any difference between conversation and the other registers concerning their basic element order, such that one kind of register admits SVO and SOV, and the other kind of register admits only SVO, it is the other registers that tend to admit only SVO. Q.E.D.

4. Note. The scale format $>\operatorname{sem}(\mathrm{A}+\mathrm{B}, \mathrm{A})$ is new. Any scale of the format in combination with another scale reflects the well-known observation that what is more semnatural (less marked) is more varied. Some examples utilizing the new format are collected in Orešnik 2000b. Turning to the subject-matter of the present deduction, conversation is more natural than the other registers; conversation accomodates both the element order SVO and the element order SOV, whereas the other registers are limited to the element order SVO.

The above deductions witness that sem-values can be utilized with profit. However, the use of sem-values in naturalness scales is only a matter of convenience. It is simply the case that sometimes the data make the formulation of a sem-scale easier than the formulation of a corresponding sym-scale. I am not aware of any deduction in which sem-values would be unavoidable.

\section{References}

Anderson, John M., "Case". In: Brown \& Miller eds. 1999, 58-65.

Boolu, Geert, Christian Lehmann, and Joachim Mugdan (eds.), Morphologie: ein internationales Handbuch zur Flexion und Wortbildung. Volume I. Berlin, de Gruyter. 2000.

Braune, Wilhelm, Gotische Grammatik. Seventeenth edition, revised by Ernst A. Ebbinghaus. Tübingen, Niemeyer. 1966.

Brown, Keith, and Jim Miller (eds.), Concise encyclopedia of grammatical categories. Amsterdam, Elsevier. 1999.

Charisteria Gvilelmo Mathesio qvinquagenario a discipulis et Circuli lingvistici pragensis sodalibvs oblata. Prague, Pražský linguistický kroužek. 1932.

DOTTER, Franz, Nichtarbitrarität und Ikonizität in der Syntax. Hamburg, Buske. 1990.

DrEsSLER, Wolfgang U., Willi Mayerthaler, Oswald Panagl, and Wolfgang U. Wurzel, Leitmotifs in natural morphology. Amsterdam, John Benjamins. 1987.

Dressler, Wolfgang U., "Naturalness". In: Booij et al. eds. 2000, 288-96.

GreenBerG, Joseph H., Language universals. Haag, Mouton. 1966.

HIRT, Hermann, Handbuch des Urgermanischen. II. Stammbildungs- und Flexionslehre. Heidelberg, Winter. 1932.

HIRT, Hermann, Handbuch des Urgermanischen. III. Abriss der Syntax. Heidelberg, Winter. 1934.

JACOBS, Joachim, Armin von Stechow, Wolfgang Sternefeld, and Theo Vennemann (eds.), Syntax. Volume I. Berlin, de Gruyter. 1993

JAKOBSON, Roman, "Zur Struktur des russischen Verbums". In: Charisteria 1932, 74-84.

KENESEI, István, Robert M. Vago, and Anna Fenyvesi, Hungarian. London, Routledge. 1998.

KovAČ́Č́, Irena, Milena Milojević-Sheppard, Silvana Orel-Kos, and Janez Orešnik (eds.), Linguistics and language studies: Exploring language from different perspectives. Ljubljana, Filozofska fakulteta. 2000.

KozIAnKA, Maria, "Negation und Modus im Germanischen". Paper abstract. Würzburg, 1999.

LiChTENBERK, Frantisek, "Reflexives and reciprocals". In: Brown \& Miller eds. 1999, 313-9.

LyONS, Christopher, Definiteness. Cambridge, Cambridge University Press. 1999.

MAyerthal.er, Willi, Morphologische Natürlichkeit. Wiesbaden, Athenaion. 1981. - English version: Mayerthaler 1988. 
MAYERTHALER, Willi, "System-independent morphological naturalness". In: Dressler et al. 1987, 25-58.

MAYERTHALER, Willi, Morphological naturalness, Ann Arbor, Karoma. 1988.

MaYerThaler, Willi, and Günther Fliedl, "Natürlichkeitstheoretische Syntax". In: Jacobs et al. eds. 1993, 610-35.

MAYERTHALER, Willi, Günther Fliedl, and Christian Winkler, Infinitivprominenz in europäischen Sprachen. Teil I: Die Romania (samt Baskisch). Tübingen, Narr. 1993.

MAYERTHALER, Willi, Günther Fliedl, and Christian Winkler, Infinitivprominenz in europäischen Sprachen. Teil II: Der Alpen-Adria-Raum als Schnittstelle von Germanisch, Romanisch und Slawisch. Tübingen, Narr. 1995.

MAYERTHALER, Willi, Günther Fliedl, and Christian Winkler, Lexikon der natürlichkeitstheoretischen Syntax und Morphosyntax. Tübingen, Stauffenburg. 1998.

OREŚNIK, Janez, "Naturalness: The English s-genitive and of-phrase". Studia anglica posnaniensia 34, 191-200. 1999.

OREŠNIK, Janez, "Naturalness: The preterite and present perfect tenses in German". In: I. Kovačič et al. eds. $2000 \mathrm{a}, 21-43$.

OREŠNIK, Janez, "Naturalness: The scale formats $>$ sem $(+/-A,-A)$ and $>$ sem $(+/-A,+A)$ ". Linguistica 40 , 237-62. $2000 \mathrm{~b}$.

OREŠNIK, Janez, "Naturalness: The passive in the mainland Scandinavian languages". Sprachtypologie und Universalienforschung 54, 26-34. 2001 a.

OREŠNIK, Janez, "Naturalness: Some Slovenian (morpho)syntactic examples". Slovenski jezik - Slovene Linguistic Studies 3, 3-31. $2001 \mathrm{~b}$.

SCHACHTER, Paul, "Part-of-speech systems". In: Shopen ed. I 1985, 3-61.

SHOPEN, Timothy (ed.), Language typology and syntactic description. Three volumes. Cambridge, Cambridge University Press. 1985.

SiEWIERSKA, Anna, "Word order and linearization". In: Brown \& Miller eds. 1999, 412-8.

SNOJ, Marko, Kratka albanska slovnica [Brief Albanian grammar]. Ljubljana, Filozofska fakulteta. 1991.

STOLZ, Thomas, Sekundäre Flexionsbildung. Eine Polemik zur Zielgerichtetheit im Sprachwandel. Two volumes. Bochum, Brockmeyer. 1992.

TOPORIŠLč, Jože, Slovenska slovnica [Slovenian grammar]. Fourth (revised and augmented) edition. Maribor, Obzorja. 2000.

TSCHERnyCH, Petr J., Historische Grammatik der russischen Sprache. Halle, Niemeyer. 1957.

WURZEL, Wolfgang Ullich, Flexionsmorphologie und Natürlichkeit. Berlin, Akademie-Verlag. 1984.

ZEMSKAJA, Elena A., Russkaja razgovornaja reč': lingvističeskij analiz i problemy obučenija [Colloquial Russian: Linguistic analysis and problems of teaching methods]. Moskva, Russkij jazyk. 1979. 


\section{Povzetek}

\section{JEZIKOVNA NARAVNOST IZRAŽENA V SEM-VREDNOSTIH}

V Sloveniji smo naravno skladnjo celovške šole razširili v "slovensko teorijo", ki raziskuje vedenje sopomenskih in domala sopomenskih (obliko)skladenjskih izrazov, tu imenovanih skladenjske dvojnice. Bistveni del znanstvenega aparata tvorijo povezave visokih in nizkih sym- in semvrednosti, pridobljenih iz lestvic jezikovne naravnosti.

Sestavek prinaša zglede, $v$ katerih se visoka sem-vrednost povezuje $z$ najmanj še eno visoko semvrednostjo, in zglede, $v$ katerih se nizka sem-vrednost povezuje $z$ najmanj še eno nizko sem-vrednostjo. Doslej take povezave $v$ okviru teorije o jezikovni naravnosti niso bile deležne pozornosti.

Ponazoritve se naslanjajo na jezikovno gradivo, razvrščeno v 14 "izpeljav". Uporabljeni jeziki: albanščina, estonščina, francoščina, germanski jeziki (stari), gotščina, italijanščina, lakhota, laponščina, madžarščina, pajute in ruščina, v uvodnem zgledu slovenščina. 